\title{
Opium and Migration: Jardine Matheson's Imperial Connections and the Recruitment of Chinese Labour for Assam, 1834-1839
}

\author{
Opium and Migration
}

\author{
STAN NEAL \\ University of Leicester, United Kingdom \\ Email: sn251@le.ac.uk/stan.neal@outlook.com
}

\begin{abstract}
This article examines the role of the private merchant firm Jardine Matheson in procuring Chinese tea cultivators for the East India Company's experimental tea plantations in Assam in the 1830s. Where existing literature has detailed the establishment of a Tea Committee by the East India Company to oversee these tea plantations, the focus of this article is on the way that the illicit opium distribution network of Jardine Matheson was used to extract labour, tea specimens and knowledge from China. The colonial state's experimental tea plantations were directly connected to the devastation of the opium trade. The multiple uses of Jardine Matheson's drug distribution networks and skilled employees becomes evident upon examination of their role in facilitating Chinese migration. The recruitment of tea cultivators from China in the 1830s also impacted on colonial concepts of racial hierarchy and the perceived contrast between savagery and civilization. Ultimately, Jardine Matheson's extraction of skilled labour from the China coast informs our understanding of the evolving private networks that became crucial to British imperialism in Asia, and through which labour, capital, people, information and ideas could be exchanged.
\end{abstract}

* I am grateful to my supervisors, Joseph Hardwick, Tanja Buletmann and Tony Webster, for their support and advice as I researched this topic. I would also like to thank my examiners, Robert Bickers and David Gleeson, as well as the anonymous reviewers at Modern Asian Studies for their comments and feedback. All errors and oversights are mine alone. 


\section{Introduction}

The 1830s, a decade of tumultuous Anglo-Chinese diplomatic relations, were marked by British fears about the future supply of tea from China. ${ }^{1}$ Politicians and tea merchants worried that an over-reliance on a single producer that lay outside direct colonial authority would leave Britain's tea supply, and therefore Britain's import revenues and the East India Company's (hereafter EIC) profitability, at risk. ${ }^{2}$ Consequently, the discovery of wild tea plants in the Northeast Indian region of Assam provided scope for British-owned tea production and an opportunity to move away from commercial reliance on China. The drawback, as pointed out by Jayeeta Sharma, was that China and tea were 'synonymous' and that metropolitan consumers would be suspicious of new, Indian, tea. ${ }^{3}$ This article will examine one of the solutions that was offered to this conundrum: the recruitment of Chinese tea cultivators to work on tea plantations in Assam. ${ }^{4}$ Sharma's Empire's Garden and Antrobus' much earlier narrative history of the Assam Company have been the main scholarly texts to document this experiment with Chinese labour in India. ${ }^{5}$ These texts offer a detailed insight into the transformation of Assam under British rule, including the role of Chinese tea cultivators, but the focus on the development of the Assam region itself has shed little light on how Chinese labourers were recruited in China. By scrutinising the process by which these specialist cultivators were procured we can gain a deeper understanding of developing commercial networks and racial hierarchies in the British Empire in Asia in the 1830s. The British merchant firm Jardine Matheson was crucial to the recruitment and transport of Chinese tea cultivators for Assam. As a result the firm lies at the centre of this article's analysis.

Jardine Matheson are ubiquitous in histories of Anglo-Chinese relations and the First Opium War. ${ }^{6}$ However, the firm is usually presented in the guise of drug dealer, war monger or free trade advocate. Its position as a facilitator of emigration has been overlooked. Despite being a 'state-run' operation under the auspices of the Indian Government, the Assam experiment was entirely reliant on this private company's opium distribution network to source skilled labour. This indicates the transformation of the mechanisms of Anglo-Chinese commercial relations up to the early 1830s. These changes were a product of the EIC Charter Act of 1833 and the consequent proliferation of unregulated private British commercial

\footnotetext{
${ }^{1}$ British concern over maintaining access to Chinese markets in the 1830s has been discussed in depth in the following articles: John M. Carroll, 'The Canton System: Conflict and Accommodation in the Contact Zone', Journal of the Royal Asiatic Society Hong Kong Branch, Vol. 50, 2010, pp. 51-66; Hao Gao, 'Prelude to the Opium War? British reactions to the 'Napier Fizzle' and attitudes towards China in the mid eighteen-thirties', Historical Research, Vol. 87, No. 237, 2014, pp. 491-509; Glenn Melancon, 'Peaceful Intentions: the First British Trade Commission in China, 1833-5', Historical Research, 73, 2000, pp. 33-47.

${ }^{2}$ Nicholas Dirks, The Scandal of Empire: India and the Creation of Imperial Britain, Harvard University Press, London, 2008, p. 143.

3 Jayeeta Sharma, 'Lazy Natives, Coolie Labour, and the Assam Tea Industry', Modern Asian Studies, Vol. 43, No. 6, November 2009, p. 1289.

${ }^{4}$ This was only one solution, as will be seen throughout the article other sources of labour were later used.

${ }^{5}$ Jayeeta Sharma, Empire's Garden: Assam and the Making of India, Duke University Press, London, $2011 ; \mathrm{H}$. A. Antrobus, The History of the Assam Company, 1839-1953, T. and A. Constable Ltd., Edinburgh, 1957.

${ }^{6}$ A good overview of the range of Jardine Matheson's commercial activities is Carol Matheson Connell, $A$ Business in Risk: Jardine Matheson and the Hong Kong Trading Industry, Praeger, London, 2004.
} 
expansion on the China coast. ${ }^{7}$ Crucially the 'opening' of China to new private firms was supported and abetted by the British state, though it was not uncontested by imperial and metropolitan commentators. ${ }^{8}$ The spectre of the Opium War has led to the oversimplification of the role of firms like Jardine Matheson in the expansion of British imperial and commercial interests in Asia. The recruitment of tea cultivators for Assam demonstrates the many roles that the firm performed on the China coast. ${ }^{9}$

In the early 1830s Jardine Matheson began conducting exploratory voyages along the China coast to find new opium markets outside of the Canton system of trade regulation. Capital from opium smuggling operations was re-invested by the firm into the legal tea trade. Effectively the firm acted as a go-between for business clients who lacked the 'knowledge and clout' to conduct such operations themselves. ${ }^{10}$ As Carol Matheson Connell has detailed, the firm offered sixteen different 'agency' services that revolved around broking for buyers and sellers of goods to and from India, China and Britain. ${ }^{11}$ Services provided included sales, arranging insurance, chartering ships, obtaining freight and transhipping goods. These services could be applied to any number of imported or exported products, such as tea or silk, but the firm's most important customer was Parsee merchant Jamsetjee Jejeebhoy, who supplied the firm with Indian-grown opium for sale on the China coast, which accounted for the bulk of their business growth in the 1830s. ${ }^{12}$ The firm made profit through the commission charged on sales made on behalf of sellers such as Jejeebhoy. Crucially, the firm's opium voyages were not purely used for selling opium and extracting capital; they were also channels through which biblical literature was circulated, tea cultivators were recruited, valuable plant samples were sourced, and various forms of 'useful knowledge' were acquired and disseminated. ${ }^{13}$

The importation of Chinese labour into Assam in the 1830s is particularly significant given that India was a net exporter of labour over the nineteenth century. The abolition of slavery in the British Empire in 1833 exacerbated existing labour shortages in plantation colonies, and created a demand for Indian 'coolie' labour. ${ }^{14}$ Colonies such as Sri Lanka,

\footnotetext{
${ }^{7}$ See Yukihisa Kumagai, Breaking into the Monopoly: Provincial Merchants and Manufacturers' Campaigns or Access to the Asian Market, 1790-1833, Brill, Boston, 2013 for an overview of the campaigns to remove the EIC monopoly of the China trade.

${ }^{8}$ This is particularly evident in the failed Napier expedition of 1834 .

${ }^{9}$ Though many texts have discussed the firm in depth none have addressed Jardine Matheson's role in facilitating Chinese emigration, see Connell, A Business in Risk; W.E. Chong, Mandarins and Merchants: Jardine Matheson \& Co., a China agency of the early nineteenth century, Curzon Press, London, 1979; Robert Blake, Jardine Matheson: Traders of the Far East, Weidenfield and Nicholson, London, 1999; Maggie Keswick (ed.), The Thistle and the Jade: A Celebration of Jardine, Matheson \& Co., Octopus, London, 1982.

${ }^{10}$ Connell, A Business in Risk, p. 6.

${ }^{11} \mathrm{Ibid}$.

12 Alain Le Pinchon (ed.), China trade and empire: Jardine, Matheson \& Co. and the origins of British rule in Hong Kong, 1827-1843, Oxford University Press, Oxford, 2006, p. 33.

${ }^{13}$ The extraction of 'useful knowledge', such as knowledge of tea cultivation, from China has been the subject of recent scholarly inquiry, see Maxine Berg, 'Britain, Industry and Perceptions of China: Matthew Boulton, "useful knowledge" and the Macartney Embassy to China', Journal of Global History, Vol. 1, No. 2, 2006, pp. 269-288 and Songchuan Chen, 'An Information War Waged by Merchants and Missionaries at Canton: The Society for the Diffusion of Useful Knowledge in China, 1834-1839', Modern Asian Studies, Vol. 46, No.6, 2012, pp. 17051735.

14 The term 'coolie' (deployed with caution due to its pejorative usage) is derived from the Tamil term Kuli, meaning hire; Gaiutra Bahadur, Coolie Woman: The Odyssey of Indenture, Hurst \& Co., London, 2013, p. xx.
} 
Mauritius and the West Indies became destinations for Indian migrant labourers. ${ }^{15}$ An estimated 430,000 Indian emigrants worked on plantations in the West Indies between 1834 and 1918. ${ }^{16}$ These manual labourers were low-paid, endured poor passage and working conditions, and were often coerced into migration. Such problems led to the prohibition of Indian emigration in 1839, before it was resumed under state supervision from 1842 onwards. ${ }^{17}$ The use of Indian emigrant labour in the British Empire over the nineteenth century was driven by the development of colonial plantation economies. Consequently, the example of Chinese immigration to Assam actually fits within the same broad process as Indian emigration. Indeed, Assam itself was the destination for over 700,000 migrant labourers from other regions of India between 1870 and $1900 .{ }^{18}$ In the 1830s, it was the specific knowledge of Chinese tea cultivators that was required in Assam. Across the British Empire plantation agriculture was developed by specialist skilled labourers and sustained by unskilled, and often exploited, labourers.

This article will examine two stages of recruitment for the Assam plantations. First, the opium voyages that Charles Gutzlaff and George Gordon undertook along the China coast in search of tea cultivators and tea seeds in 1834 will be detailed. At this point Gutzlaff, primarily a missionary, was employed by Jardine Matheson as an interpreter on their opium trading vessels. These same vessels provided Gutzlaff and Gordon with access to parts of China otherwise closed to 'foreigners'. Second, the focus will be on the recruitment of tea cultivators by James Matheson personally in 1839 and the subsequent recruitment under the Assam Company. The recruitment of Chinese tea cultivators in the 1830s highlights the importance of Jardine Matheson's commercial network and expertise in the development of new imperial resource pools, like Assam, which would be hugely significant in ensuring the future profitability of the Indian Government. ${ }^{19}$ Though the firm's primary concern was extracting Chinese capital for its own benefit through the opium trade, its operations allowed the accessing skilled labour, plant resources and specialist knowledge from areas of China that lay beyond the reach of Britain's official commercial or diplomatic structures.

The Assam tea plantations also acted as a new 'contact zone' in which racial hierarchies were constructed and tested. ${ }^{20}$ As has been discussed by Jayeeta Sharma, the 'civilized' Chinese tea cultivators acted as a counterpoint to the 'savage' Assamese natives in the colonial mind-set. ${ }^{21}$ The situation was, however, never quite so simple. Attitudes towards Chinese cultivators were also informed by a sense of mistrust and, in spite of colonial hierarchies, indigenous peoples came to play an essential role in the production of Assam tea through their

\footnotetext{
${ }^{15}$ Roland Wenzlhuemer, 'Indian Labour Immigration and British Labour Policy in Nineteenth-Century Ceylon', Modern Asian Studies, Vol. 41, Issue 3, May 2007, p. 583.

${ }^{16}$ L. L. Walton, Indentured Labour, Caribbean sugar: Chinese and Indian migrants in the British West Indies, 1838-1918, The Johns Hopkins Press, Baltimore, 1993, p. 19.

${ }^{17}$ Hugh Tinker, A New System of Slavery: the export of Indian Labour Overseas, 1830-1920, Oxford University Press, London, 1974, p. 69.

${ }^{18}$ Ibid, p. 50.

${ }^{19}$ Following the 1833 Charter Renewal the EIC was no longer a commercial organisation, but was an instrument of government.

20 The 'contact zone' concept is taken from Mary Loiuse Pratt, Imperial Eyes: Travel Writing and Transculturation Routledge, London, 1992. See Ulrike Hillemann, Asian Empire and British Knowledge: China and the Networks of British Imperial Expansion, Palgrave Macmillan, New York, 2009 for more on contact zones as sites within which knowledge of China and racial hierarchies were simultaneously constructed.

${ }^{21}$ Sharma, Empire's Garden.
} 
knowledge and labour. Yet these narratives of racial superiority and stratification were connected to the recruitment of labour. In fact, they were reliant on the supply of 'genuine' Chinese tea cultivators from Jardine Matheson. The recruitment of Chinese tea cultivators from the China coast in the 1830s fed into both the economic development of British imperialism in Asia and the ideologies of racial hierarchy that were used to justify colonial control.

\section{The Assam Project}

The Tea Committee was established by the EIC in January 1834 under the direction of Governor-General of India William Bentinck in order to begin the experimental cultivation of tea in Assam. ${ }^{22}$ The 'discovery' of the tea plant's wild growth in Assam has been attributed to Scottish trader Robert Bruce in 1823, though samples of the plant were not remitted to the Indian authorities until 1831 by his brother Charles Bruce, who was an EIC gun-boat commander in the region. ${ }^{23}$ The discovery was not widely reported in Britain until the mid1830s. In reports in Britain the role of the Bruce brothers was often overlooked, with a focus on Charles's military superiors: 'Tea plant discovered in Assam by Captain Jenkins and Lieutenant Charlton, who had forwarded samples' ${ }^{24}$ The time it took for Robert Bruce's 1823 discovery to be confirmed and the confusion over the specific details of the discovery highlights the remoteness of the Assam region, from which information, people and resources were slow to travel. The distance from Calcutta to the main station at Nazira was roughly 1000 kilometres and it took around two months to make the journey in one direction. The discovery of the wild tea plant was reported on the China coast in the Canton Register in $1835 .{ }^{25}$ By the mid-1830s the existence of tea plant growing wild in Assam was common knowledge in both Britain and across the British Empire in Asia.

The Tea Committee relied on the expertise of several key individuals. From 1834 Charles Bruce, in addition to his military responsibilities, took charge of the experimental plantations in Assam due to his knowledge of the region's geography. By 1836 he would have to take up the role full time at a salary of 400 rupees. ${ }^{26}$ George J. Gordon was initially appointed secretary of the Tea Committee, which would oversee the operation from Calcutta. Gordon had been a long-time employee of the bankrupt Indian merchant firm Mackintosh \& Co., leading Bentinck to comment that he knew 'no one better qualified'. ${ }^{27}$ Importantly, Mackintosh \& Co. feature heavily in the Jardine Matheson archive's accounts, invoices, business and private letters over the $1820 \mathrm{~s}^{28}$ James Matheson worked as an apprentice at Mackintosh \& Co. from 1815 as the firm was run by his uncle. ${ }^{29}$ Through this experience Gordon was intimately

\footnotetext{
${ }^{22}$ Antrobus, The History of the Assam Company, p.5; Anonymous, Assam: a sketch of its history, soil, and productions, Smith, Elder \& Co., London, 1839, p. 24.

${ }^{23}$ Of course, the idea of a 'discovery' is a Western misnomer, locals had long made use of the tea plant; S. K. Sharma and Usha Sharma (eds), North-East India: Volume 5 Assam - Economy, Society and Culture, Mittal, New Delhi, 2005, p. 40.

${ }^{24}$ Reading Mercury, 4 May 1835.

${ }^{25}$ Canton Register, 6 October 1835; The Register was owned and printed by James and Alexander Matheson.

${ }^{26}$ Captain F. Jenkins to N. Wallich (5 May 1836), Parliamentary Papers, Tea Cultivation, p. 70.

${ }^{27}$ W. C. Bentinck, Calcutta, (24 January 1834), Parliamentary Papers, Tea Cultivation, p. 6.

${ }^{28}$ Jardine Matheson Archive, (Cambridge University Library),

[http://janus.lib.cam.ac.uk/db/node.xsp?id=EAD/GBR/0012/MS\%20JM], accessed 7 May 2016.

${ }^{29}$ Le Pinchon, China Trade and Empire, p. 24.
} 
knowledgeable of the China trade and connected to the private merchant houses at Canton. When Gordon was despatched to source tea seeds and tea cultivators from the China coast in 1834 he was replaced by Dr Nathaniel Wallich as Secretary. Wallich was the director of the EIC's botanic garden at Calcutta and was highly regarded for his expert knowledge of tea seeds and plants. He had been cultivating Assam tea samples sent by Bruce in Calcutta. Bentinck wrote to the Tea Committee in January 1834 that 'the best evidence obtainable perhaps, not only in India, but elsewhere, is that of Dr. Wallich'. ${ }^{30}$ The premium placed on knowledge and expertise, whether local, commercial or scientific, was evident in the composition of the Tea Committee.

As employees of the EIC the Tea Committee members were well aware of the commercial benefits for Indian, British and private revenues once Britain secured an imperial tea supply. The state of commercial relations with China had been a primary concern of the 1833 EIC Charter Act, which removed the Company's monopoly and oversight over the British merchants at Canton. ${ }^{31}$ As the Tea Committee was established in 1834, so to William Napier, the first 'Superintendent of the China Trade', was despatched to Canton. Though Napier famously failed to aggressively establish a new diplomatic protocol, it must be emphasised that the primary concern of British foreign policy under Palmerston was not necessarily to overtly challenge the Chinese state, but to maintain and protect the tea trade from potential disruption. ${ }^{32}$ Similarly, the first line of the Tea Committee's 'proposition' neatly surmised their view that 'the commercial relations of this country with China have lately assumed a character of uncertainty'. ${ }^{33}$ The tea trade's economic value meant its continuation was a priority for both Indian and British authorities - by the 1830s it brought $£ 4$ million per annum to the EIC and provided seven per cent of Britain's public revenue in excise duties. ${ }^{34}$ The main problem with the tea trade was that its profitability was contingent on the illegal importation of opium to China by private merchant firms such as Jardine Matheson. This illicit trade was simultaneously the catalyst for the decline in Anglo-Chinese relations, which in turn threatened the continuation of the tea supply as Chinese authorities threatened to suspend trade as a response to British opium smuggling. An Indian supply of tea would circumvent China, meaning any diplomatic breakdown over opium smuggling would not threaten the lucrative trade.

In addition to the economic benefits of Indian tea production, the language used by Tea Committee members demonstrated an attitude of civilizational superiority that was ubiquitous in British imperial planning. ${ }^{35}$ The Secretary, Wallich, made the case that it was imperative to not be 'dependent on the will and caprice of a despotic nation for the supply of one of the

\footnotetext{
${ }^{30}$ Minute by the Governor General (24 January 1834), Parliamentary Papers, Tea Cultivation, p. 5.

${ }^{31}$ Parliamentary Papers, A bill to Regulate the Trade to China and India, 1833 (528).

${ }^{32}$ Melancon, 'Peaceful Intentions', p. 33-47; Gao, 'Prelude to the Opium War', pp. 491-509.

${ }^{33}$ Proposition to the Honourable Directors of the EIC to Cultivate Tea upon the Nepaul Hills, and such other parts of the Territories of the EIC as may be suitable to its growth. By Mr. Walker, Parliamentary Papers, Tea Cultivation, p. 6.

${ }^{34}$ Philip Lawson, The East India Company: A History, Longman, London, 1993, p. 157.

35 See Jennifer Pitts, A Turn to Empire: the Rise of Imperial Liberalism in Britain and France, Princeton University Press, Princeton, 2005 on the centrality of civilizational superiority as the guiding philosophy of imperial expansion.
} 
greatest comforts and luxuries of civilized life' ${ }^{36}$ Here Wallich implied not only that the cultivation and consumption of tea was a mark of civilization, but that the Chinese state, as 'despotic', was inherently untrustworthy. For Wallich, the future of Britain's tea supply could not be left to the Chinese state or Assamese natives, but required the guidance and management of the civilized British.

Plans for British tea production in Assam faced one major obstacle: for all of the Tea Committee's expertise they lacked the experience and knowledge of large-scale tea cultivation. The Chinese monopoly of mass tea production was based on a monopoly of knowledge, which, in the words of Antrobus, was 'guarded jealously'. ${ }^{37}$ Bringing Chinese tea cultivators to Assam to transfer such knowledge would be a critical in place of an isolationist Chinese state. Much of Charles Bruce's writing on the operations in Assam was concerned with learning processes from Chinese cultivators and de-monopolising this specialist knowledge. His Account of the Manufacture of the Black Tea included lengthy dialogue and centred on practical questions such as 'Does the Tea plant grow mostly on the mountains of China or in the valleys?', 'Does the Tea plant grow amongst the snow?' and 'How do you plant the Tea seeds?' ${ }^{38}$ Without Chinese expertise Bruce was unable to replicate the production of tea as undertaken in China, which was crucial to the tea's commercial success in Britain. The British public was used to consuming Chinese tea and the Tea Committee believed that Chinese involvement would provide the final product with a level of authenticity. ${ }^{39}$ From the outset it was clear that Chinese tea cultivators could be replaced once the British public was used to the Assam brand and their knowledge had been transferred to British overseers and Indian artisans. Samuel Ball's writing, based on observation of India and China from 1804 to 1826, suggested that 'tea can be produced in India at no greater cost than China. ${ }^{40}$ Ball compared the living expenses of Indian and Chinese labourers and concluded that 'so far as the wants of the two people, and wages of labour are concerned, India possesses no small advantage over China for the successful cultivation of tea. ${ }^{41}$ Once Bruce was able to successfully manage a large-scale tea plantation, with enough workers skilled in the art of Chinese-style tea cultivation, the future of the tea production in Assam would be Indian labourers under British instruction. Ultimately the need for Chinese tea cultivators in Assam was driven by the short term needs of the Tea Committee and of Bruce, on the ground, in Assam.

As well as the need for Chinese expertise to both produce and provide marketable legitimacy for the tea, the desire for Chinese labour was also influenced by colonial concepts of racial hierarchy. For John Crawfurd, the former Bengal Medical Service employee and British Resident of Singapore, the very existence of a Chinese tea industry and absence of an Indian tea industry was indicative of Chinese superiority. Writing in 1829 Crawfurd determined that the Chinese 'character' was 'peculiarly adapted to the tedious manipulation indispensable

${ }^{36}$ Observations on the Cultivation of the Tea plant, for Commercial purposes, in the mountainous parts of Hindostan; drawn up at the desire of the Right honourable C. Grant, President of the Board of Control for Indian Affairs, by N. Wallich, British Parliamentary Papers, Tea Cultivation, p. 15.

${ }^{37}$ Antrobus, The History of the Assam Company, p. 30.

${ }^{38}$ C. A. Bruce, An Account of the Manufacture of the Black Tea, As now practised at Suddeya in Upper Assam, Bengal Military Orphan Press, Calcutta, 1838, pp. 6-7.

${ }^{39}$ Sharma, 'Lazy Natives, Coolie Labour, and the Assam Tea Industry', p. 1291.

${ }^{40}$ Samuel Ball, An Account of the Cultivation and Manufacture of Tea in China, Longman, London, 1848, p. 335.

${ }^{41}$ Ibid, p. 342. 
to the preparation of tea' ${ }^{42}$ By contrast Crawfurd lamented that 'not one pound of tea has ever been grown in our Indian possessions' in spite of the similar climatic conditions and the wild growth of the tea plant. ${ }^{43}$ This failure was ascribed to the 'unskillfulness of the Indians in almost everything approaching to manufacturing' in contrast to the 'superior skill of the Chinese'. ${ }^{4}$ The cultivation of tea not only required specialist knowledge, but it implied skill and consequently a degree of civilization. The lack of a pre-existing Indian tea industry was interpreted by colonial observers as an indictment of Indian civilization more generally. Importantly Crawfurd's opinion was that of a well-respected and experienced expert, with currency in both India and Britain. ${ }^{45}$

While Crawfurd criticised the 'Indians' generally, other British observers maligned the population of Assam specifically. Jayeeta Sharma's work has discussed how the Assamese were perceived, by colonial authorities, to be lazy and opium addicted. ${ }^{46}$ Opium, like tea, grew naturally in the region and addiction amongst the Assamese was seen to be such a problem that private opium cultivation was banned and the Indian Government was given a monopoly of opium production in the area in $1861 .{ }^{47}$ Charles Bruce lamented how opium 'has degenerated the Assamese from a fine race of people to the most abject, servile, crafty and demoralized race in India' ${ }^{48}$ Not only was Assamese savagery emphasised by those on the ground, such as Bruce, but it was directly contrasted with Chinese civilization in contemporary scientific discourse. Dr John McCosh, also of the Bengal Medical Service, wrote accounts of the region's typography that were reprinted in both British and colonial newspapers and journals. Writing in the Singapore Chronicle he emphasised how Assam was 'thinly populated by strangling hordes of slowly procreating barbarians, and allowed to lie profitless in a primeval jungle', but not completely cut off from enterprising 'Chinese merchants, [who] by a short land journey across these mountains convey [sic] their merchandise on mules'. ${ }^{49}$ The mountainous border between Assam in North East India and Yunnan in North West China was constructed as a line between savagery and civilization. This division fits within the broad tradition of state formation in Southeast Asia discussed by James C. Scott. The Assamese 'hill tribes' were viewed as a 'barbarian periphery' that would either have to be changed or removed in order for the British to achieve their aim of commercial tea production. ${ }^{50}$ In the 1830 s context the Chinese were not only necessary as tea cultivators with specific expertise, but were expected

\footnotetext{
42 John Crawfurd, View of the Present state and Future Prospects of the Free Trade and Colonisation of India, James Ridgway, London, 1829, p. 18.

43 Ibid.

${ }^{44}$ Ibid, p. 19.

${ }^{45}$ For more on the role of Crawfurd's influence on debates over the EIC see Yukihisa Kumagai, Breaking into the Monopoly: Provincial Merchants and Manufacturers' Campaigns or Access to the Asian Market, 1790-1833, Brill, Boston, 2013, pp. 76-113.

${ }^{46}$ Sharma, Empire's Garden, p. 5.

${ }^{47}$ Sharma, 'Lazy Natives, Coolie Labour, and the Assam Tea Industry', p. 1297; The peculiar irony being that Chinese opium addiction had maintained the economic viability of the tea trade.

${ }^{48}$ George Thompson, Report of a Public Meeting and Lecture at Darlington ... on China and the Opium Question, J. H. Veitch, Durham, 1840, p. 13.

${ }^{49}$ Singapore Chronicle, 6 August 1836; Asiatic Journal, Vol. 26, 1838.

50 James C. Scott, The Art of not Being Governed: An Anarchist History of Upland Southeast Asia, Yale University, New Haven, 2009, pp. 1-40.
} 
to provide an industrious, skilled and compliant labour force in contrast to native laziness and resistance. ${ }^{51}$

It was decided by the Tea Committee that the initial experiment in tea production would require a limited number of Chinese experts 'employed to instruct the natives' under the direction of Charles Bruce in Assam. ${ }^{52}$ This plan was partly modelled on the Dutch use of Chinese tea cultivators in Java and heavily influenced by existing systems of Chinese migration in the British Empire. ${ }^{53}$ Governor-General Bentinck had travelled to Malacca and Singapore in 1829 to 'observe the Chinese character' and had been impressed. ${ }^{54}$ Again, this elevation of 'character' underlines how concepts of hierarchy factored into the Tea Committee's decision making. Bentinck later outlined his plan that an agent should be appointed to obtain Chinese tea cultivators and samples of Chinese tea plants. ${ }^{55}$ As a result of Bentick's instructions, Tea Committee Secretary George J. Gordon proceeded to the China coast in 1834 to procure Chinese tea seeds and tea cultivators. ${ }^{56}$ With Gordon an exploratory mission, Bruce preparing a tea plantation in Assam, and Wallich overseeing the whole operation from Calcutta, the Assam tea experiment began.

\section{George Gordon and Charles Gutzlaff on the China Coast}

In June 1834 Gordon headed, aboard the Water Witch, to Canton with instructions to gather information about Chinese tea manufacturing as well as to acquire seeds, plants and tea makers. ${ }^{57} \mathrm{He}$ was sent to Canton with 'a recommendation from this Government to the British authorities at Canton ... to procure for Mr Gordon any facilities or protection that may be found necessary', and to fund his endeavours an account for '20,000 to 25,000 dollars placed at his command'. ${ }^{58}$ That quality, rather than quantity, was required was also emphasised in Gordon's instructions: 'It will be Mr Gordon's principal duty to bring round a select, rather than numerous, body of planters; men qualified to conduct every operation connected with the production of good tea'. ${ }^{59}$ It was suggested that the project need not exceed 50 recruits. The emphasis on Chinese seeds and plants reflected Wallich's belief, which turned out to be unfounded, that they key to success was the use of the best quality Chinese seeds. ${ }^{60}$ This was contrary to the priorities of Bruce in Assam. He required the recruitment of trained cultivators

\footnotetext{
${ }^{51}$ Hillemann, Asian Empire and British Knowledge, p. 128.

${ }^{52}$ W. H. Macnaughten, Esq., Secretary to the Government of India, to the Tea Committee (18 April 1836), Parliamentary Papers, Tea Cultivation, p. 63.

${ }^{53}$ The Dutch experience is referred to in the correspondence of the Tea Committee: From the members of the Tea Committee to C. Macsween, Esq., Secretary to Government, Revenue Department (15 March 1834), Parliamentary Papers, Tea Cultivation, p. 17.

${ }^{54}$ Douglas M. Peers, 'Bentinck, Lord William Henry Cavendish- (1774-1839)', Oxford Dictionary of National Biography, Oxford University Press, 2004; online edn, Oct 2009 [http://www.oxforddnb.com/view/article/2161, accessed 5 May 2016]; Sharma, Empire's Garden, p. 35.

${ }^{55}$ Assam, p. 23.

${ }^{56}$ Ibid, p. 24.

${ }^{57}$ Antrobus, The History of the Assam Company, p. 30.

${ }^{58}$ The Tea Committee to C. Macsween, Esq., Secretary to Government, Revenue Department (15 March 1834), Parliamentary Papers, Tea Cultivation, p. 17.

${ }^{59}$ Ibid.

${ }^{60}$ Harold H. Mann, The Early History of the Tea Industry in North-East India, Reprinted from the Bengal Economic Journal, 1918, p. 12.
} 
urgently as he had a limited knowledge of how to proceed. ${ }^{61}$ With mixed priorities and instructions Gordon was especially reliant on the resources and expertise of the private opium traders on the China coast.

Despite the experiment ultimately being overseen by the Indian Government, Chinese recruitment was entirely reliant upon the expertise and resources of Jardine Matheson. ${ }^{62}$ The firm operated as one of the 'country traders' - private firms licenced to take goods from India to China so that the EIC was not directly involved in the prohibited opium trade - and they extended their opium trading operation along the China coast, far beyond the permitted trading posts of Canton and Macao, following the removal of the EIC's commercial functions in 1833. The Tea Committee did not contract Jardine Matheson directly in 1834. It was Gordon, who had been granted relative autonomy over the specifics of procurement by Bentinck, who provided the link. In correspondence with the Tea Committee Gordon referred to his 'Canton friends' and the Committee referred to the firm indirectly when noting that 'Mr Gordon has taken the precaution to engage the best services of some of his private friends residing at Canton and Macao in perfecting those arrangements' ${ }^{63}$ That Gordon had these connections to the firm is unsurprising given his and James Matheson's mutual prior involvement in Mackintosh \& Co. (the defunct Calcutta firm). Crucially, Jardine Matheson also employed Charles Gutzlaff the Prussian missionary, linguist and ethnographer - as an interpreter on their opium vessels. ${ }^{64}$ William Jardine first hired Gutzlaff for his linguistic abilities in 1829, he was an interpreter aboard the Sylph from 1832 and he led at least five more coastal voyages for the firm between 1833 and $1835 .{ }^{65}$ The hiring of Gutzlaff was a major coup for the firm, as rival trader James Innes famously remarked that he would 'give a thousand [Mexican Silver] dollars for three days of Gutzlaff' due to his proficiency in multiple Chinese dialects. ${ }^{66}$ Gutzlaff was to act as Gordon's guide as he attempted to source Chinese seeds and tea cultivators for Assam.

When Gordon arrived in Canton Gutzlaff was already further along the China coast, interpreting for Jardine Matheson's opium operation aboard the Colonel Young. Gordon made it clear in his correspondence with the Tea Committee that William Jardine was arranging for him to use the firm's opium shipping network to complete his mission:

Now, Mr. Jardine proposes despatching his vessel, called The Fairy, to wait The Colonial Young, now upon the east coast, and on board of which is Mr. Gutzlaff, with order to proceed as far north as the latitude of Nankin, with a fresh supply of goods, which The

\footnotetext{
${ }^{61}$ Antrobus, The History of the Assam Company, p. 249.

${ }^{62}$ For more on the decline of the EIC as a commercial organisation see Anthony Webster, The Twilight of the East India Company: The Evolution of Anglo-Asian Commerce and Politics, 1790-1860, Boydell Press, Woodbridge, 2009.

${ }^{63}$ Letter from Mr Gordon to Dr. Wallich, Acting Secretary to the Tea Committee, Macao (24 July 1834); Tea Committee to W. H. Mcnaughten, Esq., Secretary to the Government of India (18 September 1835), Parliamentary Papers, Tea Cultivation, p. 30.

${ }^{64}$ R. G. Tiedemann, 'Gützlaff, Karl Friedrich August (1803-1851)', Oxford Dictionary of National Biography, Oxford University Press, 2004 [http://www.oxforddnb.com/view/article/54362, accessed 5 May 2016]; Charles Gutzlaff will be used in this article as opposed to his other names and pseudonyms: Karl Gutzlaff, Philosinesis, Guo Shili Gaihan, Shande.

65 Jessie Gregory Lutz, Opening China: Karl F. A. Gutzlaff and Sino-Western Relations, 1827-1852, William B. Eerdmans, Cambridge, 2008, p. 83.

${ }^{66}$ Robert Bickers, The Scramble for China: Foreign Devils in the Qing Empire, 1832-1914, Allen Lane, London, 2011 , p.30.
} 
Fairy will deliver. The Fairy only waits the return of Mr. Matheson, who is daily expected from Bombay. The Colonel Young will return to port before the change of the monsoon, so that I shall be back in time to proceed by the first ships of the season for Bengal. ${ }^{67}$

Gordon and Gutzlaff used the firm's evolving system of opium distribution to recruit Chinese tea cultivators and the seed samples Gordon required. The Fairy, which was the first ship built to the order of Jardine Matheson, was a 'package vessel' that ran between Canton, Lintin and vessels along the coast carrying intelligence, opium and capital. ${ }^{68}$ Gordon also explained how on his voyage along the coast aboard the Fairy he would, with Gutzlaff's assistance 'make such arrangements for people, plants and seed, as, after personal examination of the quality of the tea produced' ${ }^{69}$ William Jardine, whilst doing his utmost to assist Gordon's mission, expressed some concern that Gordon and Gutzlaff's venturing inland to recruit cultivators and source plants may impact upon the firm's opium operation. In a letter to Captain Rees in 1835 he confessed his fear that extensive exploration 'may bring down the displeasure of the government Authorities on the Dealers and Boat'. ${ }^{70}$ Jardine Matheson's existing system of opium distribution on the China coast was essential in enabling Gordon to fulfil his instructions from the Tea Committee. The Indian authorities were effectively outsourcing recruitment to private merchants, through Gordon, because 1833 Charter Act meant that the EIC lacked the means to recruit itself. ${ }^{71}$ Crucially, Jardine Matheson had the resources and experience to access parts of China ostensibly closed to the West.

The role of Charles Gutzlaff highlighted the various and complementary ways in which the firm's opium distribution network could be used. Gutzlaff had arrived in the Dutch East Indies in 1826 as an agent of the Netherlands Missionary Society. ${ }^{72}$ Much like his fellow protestant missionary Robert Morrison, Gutzlaff became a pioneer of English language publishing on China with a range of titles describing different aspects of Chinese society and culture. He even claimed to be a naturalized Chinese subject following his adoption into the clan family of Kwo in Siam. ${ }^{73}$ The necessities of conversion meant Gutzlaff quickly became proficient in Chinese. This led to his hiring by Jardine Matheson as an interpreter and physician on the firm's opium clippers, in exchange for which the opium fleets would offer the opportunity to preach the gospel to potential Chinese converts beyond the confines of Canton and Macao. Jardine Matheson also funded Gutzlaff's publishing in both Chinese and English. In exchange for his work on the opium clippers the firm funded his Chinese language title Dong-xi yangkao meiyue tongjizhuan (East-West monthly magazine). ${ }^{74}$ Letters between Gutzlaff and James Matheson also demonstrate the arrangements made by Matheson to publish

\footnotetext{
${ }^{67}$ Mr. Gordon to Dr. Wallich, Macao, (24 July 1834), Parliamentary Papers, Tea Cultivation, p. 30.

${ }^{68}$ A.R. Williamson, Eastern Traders: Some Men and Ships of Jardine, Matheson \& Company, Jardine Matheson, Hong Kong, 1975, p. 152.

${ }^{69}$ Mr. Gordon to Dr. Wallich, Macao, (24 July 1834), Parliamentary Papers, Tea Cultivation, p. 30.

${ }^{70}$ William Jardine, Canton, to Captain Rees, on the Colonel Young, (9 March 1835), in MS JM/B2, Jardine Matheson Archive (Cambridge University).

${ }^{71}$ Parliamentary Papers, A bill to Regulate the Trade to China and India, 1833 (528).

72 Tiedemann, 'Karl Gutzlaff'.

73 Ibid; G.B. Endacott, A Biographical Sketch-Book of Early Hong Kong, Hong Kong University Press, Hong Kong, 2005, p. 105.

${ }^{74}$ Lutz, Opening China, pp. 76-85.
} 
English language texts on his behalf. ${ }^{75}$ Despite his personal opposition to opium smoking, access to the firm's smuggling network was invaluable for Gutzlaff to his continue his work in both dissemination and collecting 'useful' knowledge. Importantly, these different aims of the opium voyages were complementary. As described by Gutzlaff, the 'opening' of China by the West incorporated the diffusion of ideas about free trade and Christian theology into China as well the extraction of information and resources from China. ${ }^{76}$ Emigration was not excluded from this as Gutzlaff also wrote about existing systems of Chinese migration in Southeast Asia as evidence of entrepreneurial Chinese subjects circumventing the state's despotic isolationism. ${ }^{77}$ The recruitment of Chinese tea cultivators and the acquisition of guarded knowledge was part of a broader process of opening, which would ultimately, from the perspective of missionaries like Gutzlaff, lead to the spread of Christianity in China. Gutzlaff's knowledge of the China coast, the Chinese language and existing forms of emigration made him an ideal expert to assist Gordon.

Gutzlaff and Gordon were particularly successful at obtaining tea seeds and plants from inland China. Prior to his voyages with Gordon (1834-35), Gutzlaff had been collecting information about tea production. Gutzlaff's expertise had been previously utilised on an exploratory voyage along the China coast for the EIC with the aggressive former EIC supercargo Hugh Hamilton Lindsay aboard the Lord Amherst. ${ }^{78}$ Gutzlaff and Lindsay's reconnaissance on the commercial potential of China's northern ports had been endorsed by William Jardine, who recognised the 'useful information' that could be collected on such a voyage. ${ }^{79}$ In his journals of such voyages Gutzlaff gave detailed accounts of tea growth in 'Formosa', 'Fuh-chow' and 'Ke-tow' ${ }^{80}$ Even before the Tea Committee's establishment knowledge of tea cultivation had been of interest. Gutzlaff's account of an exploratory voyage in 1832 detailed conversations with 'the people from the tea plantations' which left him 'pleased with the propriety and correctness of their answers' ${ }^{81}$

To acquire plants, seeds and cultivators Gutzlaff and Gordon made their way to the teaproducing hills of Fujian. ${ }^{82}$ In May 1835 they led a small party up the Min River - which included Jardine Matheson employees from the Colonel Young - to access tea hills northwest of Fuzhou, where they were fired upon by Chinese soldiers. ${ }^{83}$ The Tea Committee had been aware of such risks when they had referred to difficulty of procuring information regarding

\footnotetext{
${ }^{75}$ For example, Gutzlaff's General Description of China was published through Jardine Matheson's agent Thomas Weeding; Charles Gutzlaff, Lintin, to James Matheson, Canton, (2 July 1834), in MS JM/B11, Jardine Matheson Archive (Cambridge University).

${ }^{76}$ Charles Gutzlaff, China Opened, Vol. I, Smith, Elder and Co., London, 1838.

${ }^{77}$ Charles Gutzlaff, A Journal of Three Voyages Along the Coast of China; in 1831, 1832 \&1833, Frederick Westley and A. H. Davis, London, 1834, p. 167.

${ }^{78}$ Bickers, The Scramble for China, pp. 48-50; Robert Bickers, 'The Challenger: Hugh Hamilton Lindsay and the rise of British Asia, 1832-1865', Transactions of the Royal Historical Society, 6th series, 22, 2012, p. 141.

${ }^{79}$ Bickers, The Scramble for China, p. 27.

${ }^{80} \mathrm{Ibid}$. Fuzhou was routinely Romanised as 'Foochow' or 'Fuh-chow', as seen in Gutzlaff's journal.

${ }^{81}$ Charles Gutzlaff, Journal of a Residence in Siam: and of a Voyage Along the Coast of China to Manchou Tartary, Chinese Repository, Canton, 1832, p. 48.

${ }^{82}$ Lutz, Opening China, p. 83.

${ }^{83}$ G. J. Gordon, 'Visit to the Ankoy Tea-District', The Asiatic Journal and Monthly Register, Vol. 17, 1835, p. 281.
} 
China and tea production. ${ }^{84}$ In extracting skilled labourers and information from outside of the limits of the Canton system Gutzlaff and Gordon were breaking multiple Chinese laws. 'Foreigners' were not allowed to visit the Chinese interior and required a permit to travel between Macao and Canton. ${ }^{85}$ Similarly, the preaching and practice of Christianity and the smuggling of opium were also banned. ${ }^{86}$ For the Chinese who collaborated with Gordon and Gutzlaff the mission the risks were even greater. The assistance of foreigners in this manner, and theoretically emigration itself, carried the penalty of death. Gordon's later writing on Anglo-Chinese relations revealed an awareness of these risks as he referred to Robert Morrison's translation of the 'Penal Laws of China'. ${ }^{87}$ Gordon noted how 'if any (Chinese subjects) are at all suspected of giving information, legal advice, or similar aid, to a foreigner, the local government immediately raises the cry of traitor! ${ }^{88}$ Gordon also referred frequently to the 'judicial murder' of foreigner Thomas Scott in 1773 as evidence of the danger that the despotic Chinese state posed to Westerners themselves. ${ }^{89}$ The risks of recruitment were mitigated by Gutzlaff's expertise. Gordon was conscious that he was largely dependent on the abilities of Gutzlaff, without whom it would 'be quite in vain to attempt a journey of such length into the interior'. ${ }^{90}$ Despite Gordon's official role as a representative of the Tea Committee he found himself dependent on the effectiveness of Jardine Matheson's illicit operation.

Though Gordon wrote freely about the tea samples he gained on his expedition with Gutzlaff the details of the recruitment of tea cultivators are vague. Gordon opted to recruit tea cultivators from the Bohea hills (Wuyi Shan), a district notable for black tea production some 300 kilometres inland, after visiting several different tea districts. Notes on the subject reveal a hierarchy of Chinese tea cultivators as he explained that 'the inferiority of Ankoy tea arises from unskilful culture and preparation of the leaf ... I made, therefore, no offer to the peasantry at Twa-Be, to accompany me to Bengal as planters'. ${ }^{91}$ Gordon recruited the Bohea planters through a 'native agent', who remained un-named, and expected the arrival of his recruits at Canton in January $1835 .{ }^{92}$ In later letters there were references to 'two emissaries' hired by Gordon for the task of 'engaging competent superintendents' from the Bohea hills once he had returned to Calcutta, whilst his 'private friends residing at Canton and Macao' finalised the arrangements. ${ }^{93}$ It seems likely that the Chinese agents and tea cultivators identities were omitted deliberately given Gordon's knowledge of Chinese law and the fact that the Tea Committee offered salaries ranging between 300 and 600 rupees per month 'according to the

\footnotetext{
${ }^{84}$ The Tea Committee to C. Macsween, Esq., Secretary to Government, Revenue Department (15 March 1834), Parliamentary Papers, Tea Cultivation, p. 17.

${ }^{85}$ Priscilla Napier, Barbarian Eye: Lord Napier in China, 1834 The Prelude to Hong Kong, Brassey's, London, 1995.

${ }^{86}$ Chen, 'An Information War Waged by Merchants and Missionaries at Canton', p. 1715.

${ }^{87}$ G. J. Gordon, Address to the People of Great Britain; Explanatory of our Commercial Relations with the Empire of China, Smith, Elder and Co., London, 1836, p. 78.

${ }^{88}$ Ibid.

${ }^{89}$ Ibid, p. 66.

${ }^{90}$ Mr Gordon to Dr Wallich (23 November 1834), Parliamentary Papers, Tea Cultivation, p. 41.

${ }^{91}$ Ibid.

${ }^{92}$ Ibid, p. 42. Bizarrely, Gordon also gave tea seeds to the widow of William Napier to plant in Scotland.

${ }^{93}$ From Tea Committee to W. H. Macnaughton (18 September 1835), Parliamentary Papers, Tea Cultivation, p. 46.
} 
degree of danger they would be exposed to in entering on a contract with foreigners' ${ }^{94}$ Considering Bruce's salary as head of the operation was 400 rupees per month these payments reflected the perceived value of skilled cultivators to the success of the Assam operation. By March 1835 it had been realised that the tea plant in Assam was viable and Gordon was recalled from the China coast. ${ }^{95}$ Though an exact number is not given, Bruce's reference to Chinese assistance within 1835 suggests the arrival of Gordon's Bohea recruits. Gordon's time on the China coast with Gutzlaff had been successful in furnishing him with tea plants and recruits, as well as knowledge of Chinese tea production for the benefit of the project. ${ }^{96}$

This first round of recruitment for the Assam project (1834-1835) was not only challenging in execution but also insufficient. Many of the issues were caused by the Tea Committee's own stipulation to Gordon that the project was experimental and required as few cultivators as possible. First, linguistic difference was an issue. The recruitment of cultivators from China had not included translators for different regional dialects. As a result it was hard to locate translators with the necessary skills without incurring extra cost. ${ }^{97}$ As the Tea Committee noted in 1836, 'the dialect spoken in that part of the province of Fahkeen bordering on Kyangse, of which those people are natives, differs very materially from that spoken on the coast of the same province'. ${ }^{98}$ The EIC was poorly resourced for such eventualities with an employee of the licence department of the police, Laon Chung, hired for the task despite being 'inferior in point of intelligence' to the first choice Dr Lumqua, a Chinese doctor in Calcutta whose proposed salary was deemed too expensive. Second, the cultivators hired by Gordon from the Bohea hills were black tea cultivators and not 'practically acquainted with the peculiar process by which the green tea-leaf is prepared for the foreign market'. ${ }^{99}$ In August 1836 Bruce had discovered the wild growth of a species of green tea. Third, the tea seeds and samples sent from China by Gordon, which arrived in Calcutta in January 1835, were in a poor condition. Of the 20,000 seed samples sent to Assam in 1835 around 90 percent died. ${ }^{100}$ In fact, Bruce's first successful samples were produced by a nursery consisting of indigenous plants. ${ }^{101} \mathrm{~A}$ personal examination of the Assam plantations by $\mathrm{Dr}$ Wallich in 1836 led to the recommendation of 'an additional number of [Chinese] planters' and plans were made for further recruitment. ${ }^{102}$

\section{James Matheson and Recruitment in $\mathbf{1 8 3 9}$}

Gordon's recruitment missions in the mid-1830s enabled the Assam tea experiment to successfully produce a marketable Indian tea. The first batch of Assam tea arrived in London

\footnotetext{
${ }^{94}$ From the Tea Committee to W. H. Macnaughten (6 August 1836), Parliamentary Papers, Tea Cultivation, p. 79. Frustratingly, this also prevents the tracking of the shipment of these tea cultivators.

95 Tea Committee (12 March 1835), Parliamentary Papers, Tea Cultivation, p. 39.

${ }^{96}$ An advertisement for his 1836 book made reference to his 'personal observation' of China.

97 W. H. Macnaughten, Esq., Secretary to the Government of India, to the Tea Committee, (11 April 1836), Parliamentary Papers, Tea Cultivation, p. 62.

${ }_{98}$ Tea Committee, to W. H. Macnaughten (14 April 1836), in Parliamentary Papers, Tea Cultivation, p. 62.

99 Tea Committee, to W. H. Macnaughten (6 August 1836), in Parliamentary Papers, Tea Cultivation, p. 78.

${ }^{100}$ J. Forbes Royle, 'Report on the Progress of the Culture of the China Tea Plant in the Himalayas, from 1835 to 1857', Journal of the Royal Asiatic Society, 12, 1850, p. 132.

${ }^{101}$ D. K. Taknet, The heritage of Indian tea: the past, the present, and the road ahead (Jaipur: IIME, 2002), p. 21.

102 Tea Committee (28 March 1836), in Parliamentary Papers, Tea Cultivation, p. 58.
} 
in November 1838, where it was inspected by metropolitan experts and adjudged to be of satisfactory quality. It was first auctioned (at an inflated price due to the high-level of public interest) in January $1839 .{ }^{103}$ The landing of the tea in Britain and the developing animosities with China meant that Assam tea and the Assam region was a hot topic of discussion in the British press in early 1839. In January various metropolitan and provincial titles remarked on the 'curiosity among commercial men to the first sale of the specimens'. ${ }^{104}$ Additionally, on 15 February, the House of Commons ordered a 'Copy of papers received from India relating to the measures adopted for introducing the Cultivation of the Tea Plant within the British Possessions in India' from the EIC. ${ }^{105}$ The resulting Parliamentary Paper, which mainly comprised the correspondence to and from the Tea Committee, was published a two weeks later by East India House. ${ }^{106}$ Most significantly the Assam Company was formed at a meeting of London merchants on the 14 February 1839 with an available capital of $£ 500,000$ in 10,000 shares of $£ 50$ each and with outspoken merchant and nobleman George Gerard de Hochepied Larpent as its Chairman. ${ }^{107}$ The privatisation of the Assam tea plantations had been planned from the outset, though the Assam Company did not take direct control of the tea plantations until early in $1840 .{ }^{108}$

Despite the success of the tea in Britain, in Assam Charles Bruce had been unhappy with the arriving Chinese cultivators. Many of Gordon's secondary recruits had arrived in Assam dishevelled and impoverished (they thought their expenses would be covered separately from their wages) and had to be compensated. Furthermore some of those recruited by Gordon from Singapore had lied about their tea-making credentials and were described by Bruce as 'headstrong and passionate'. ${ }^{109}$ Unfortunately for Bruce, high demand and interest meant that more tea was required urgently; consequently there was an immediate need for more Chinese cultivators. George Gordon had tendered his resignation to the Tea Committee in May 1836 due to 'considerations, partly public and partly private'. ${ }^{110}$ The public reason given was that his task was largely completed and it was believed that Wallich could fulfil his role. Hence, the extra labour Bruce required following the success of the Assam tea in early 1839 led to a direct approach to Jardine Matheson to supply additional Chinese cultivators.

For the 1839 recruitment Wallich approached Jardine Matheson directly, without Gordon acting as an intermediary. By this point the firm had emerged as the dominant private merchant house on the China coast. In a long, six-page letter to James Matheson Wallich explained:

\footnotetext{
${ }^{103}$ Antrobus, The History of the Assam Company, p. 265.

${ }^{104}$ Yorkshire Gazette, 19 January 1839; The Era, 13 January 1839.

105 Parliamentary Papers, Tea cultivation (India). Return to an order of the Honourable the House of Commons, dated 15 February 1839;--for, copy of papers received from India relating to the measures adopted for introducing the cultivation of the tea plant within the British possessions in India, 1839 (63).

106 This publication was approved by Robert Gordon, the Commissioner of the Board of Control, at the request of the Assam Company.

${ }^{107}$ Antrobus, The History of the Assam Company p. 37; In this meeting of the Assam Company it was discussed that the EIC had agreed to 'speedily make available' information on Assam; Minute book of the Assam Company, 12 February 1839 - 17 December 1845, MS 9924/1, London Metropolitan Archives (London).

108 Antrobus, The History of the Assam Company, p. 269.

${ }^{109}$ Ibid, p. 271.

${ }^{110}$ Gordon to the Tea Committee (16 May 1836), in Parliamentary Papers, Tea Cultivation, p. 63.
} 
The committee having already benefitted in several cases by your valuable and courteous assistance in procuring, at the insistence of their late secretary Mr G. J. Gordon, manufacturing men from China, they entertain a confident hope, that you will likewise grant cordial cooperation on the present occasion, especially as it is one of great national interest and importance. ${ }^{111}$

Wallich's reference to the experiment as being of 'great national interest and importance' belies the shared aims of the Tea Committee and the firm. Wallich's concern of Chinese isolationism as a threat to the supply of tea fitted with Jardine Matheson's desire to discredit the Chinese state as overly despotic in order justify their opium trading activities. James Matheson's famous meetings with Palmerston in 1835, and his 1836 book The Present Position and Prospects of the British Trade with China, were attempts by the firm to convince metropolitan policy makers that the subversion of the authority of the Chinese state was of national interest and importance'. ${ }^{112}$

Wallich left the fine details of recruitment to the firm's 'good judgement and execution' but gave a budget to cover 'the expenses of 60 Chinese artisans'. ${ }^{113}$ The accounts were settled through Matheson, Lyall \& Co. (a Calcutta firm set up by James Matheson's nephew Hugh). Wallich listed the job roles that needed filling. Specifically, '12 Tea-cultivators', ' 8 Box Makers and Lackerers', '8 paper manufacturers' and an interpreter of 'respectability and influence' were required urgently. ${ }^{114}$ Wallich stipulated that Matheson make the contracts explicit in explaining that expenses would not be paid in addition to the advance wages (this oversight in the previous contracts had cost the Tea Committee who had to cover the expenses). ${ }^{115}$ Given the 'national importance' of the recruitment mission James Matheson took personal responsibility for arranging the contracts. However, the firm still made use of their connection with Charles Gutzlaff. In 1835 Gutzlaff had switched from opium trading to diplomacy, being primarily employed as an interpreter by the British Superintendent of the China Trade and continuing in government service after the First Opium War. ${ }^{116}$ Matheson's references to 'brokers employed by Mr Gutzlaff', highlight Gutzlaff's ability to fulfil multiple roles at the same time and his lasting connection to the firm. ${ }^{117}$

Jardine Matheson made copies of contracts with twelve Chinese tea cultivators, which named James Matheson personally. ${ }^{118}$ All of the contracts were dated 15 August 1839 and were identical in structure. ${ }^{119}$ It is also worth noting that the terms 'tea manufacturer' and 'tea cultivator' were used interchangeably, even within the same contract. Low-a-Sam, Ko-LuLeng, Low-Su-Fok, Low-Yum-Chin, Tang-Shim Kwai, Tang-Hoau-Se, Ling-Cam-Seng, Ting

111 Nathaniel Wallich, Calcutta, to Jardine Matheson, Canton, (15 February 1839), in MS JM/C10, Jardine Matheson Archive (Cambridge University).

112 James Matheson, The Present Position and Prospects of the British Trade with China, Smith, Elder and Co., London, 1836.

${ }^{113}$ Nathaniel Wallich, Calcutta, to Jardine Matheson, Canton, (15 February 1839).

$114 \mathrm{Ibid}$; The term 'lackerer' refers to 'lacquer' and the application of this protective coating as part of the transportation process.

115 Ibid.

${ }^{116}$ Lutz, Opening China, p.91.

117 James Matheson, Hong Kong, to Dr. N. Wallich, Calcutta, (25 September 1839), in MS JM/C10, Jardine Matheson Archive (Cambridge University).

118 These contracts are still located at the Jardine, Matheson \& Co. archive at Cambridge University Library.

119 Tea Cultivator Contracts, in MS JM/F11, Jardine Matheson Archive (Cambridge University Library). 
Ateem, Low A. Jin, Low Mok Yes and Ting Jin Leng were hired as 'Tea Cultivators' and A. Sing was hired as a 'Tea Packer'. ${ }^{120}$ The surviving contracts reflect some of the concerns of the Assam project's managers, as this extract from a contract signed by 'Low-a-Sam' demonstrates:

Low-a-Sam, Tea Manufacturer who thoroughly understands the business of manufacturing tea hereby engages himself to Mr. James Matheson that he will retain to Assam for the space of five years to exercise his craft, after the expiration of which he will be permitted to return. His monthly wages are to be fifteen (15) dollars including his board. $\mathrm{Mr}$ Matheson will pay every month to Lim-Fok the relation of Low-a-Sam three (3) dollars and he himself will receive the remaining Twelve (12) dollars. He will reserve in advance three months wages forty five (45) dollars as bargain money. ${ }^{121}$

Not only was the three month advance of wages explained, as desired by Wallich, but the contract emphasised that the need for the employee to 'understand' tea manufacture. This emphasis came from a fundamental mistrust of the Chinese cultivators, both among the Tea Committee members and Jardine Matheson. Whilst Bruce complained in Assam that some recruits were believed to have exaggerated their knowledge of tea cultivation so that they would receive the lucrative wages offered. Indeed, James Matheson had previously written that the Chinese were characterised by 'imbecility, avarice, conceit, and obstinacy'. ${ }^{22}$ Given these attitudes, the accuracy of the contracts was paramount. The contract was a short document, written in both English and Chinese, and contained details such as fines for Low-a-Sam's failure to see through the contract and explicitly confirming that he would be free to return to China at the completion of the five years of service. Ensuring that Chinese cultivators understood, or at least could not claim to have misunderstood, the terms of the contract was important to the Tea Committee. As seen previously the EIC had struggled to acquire adequate translators for the tea plantations in Assam. By contrast the needs of Jardine Matheson meant they employed a vast staff of interpreters and compradors who operated their clandestine opium distribution network. ${ }^{123}$ The Tea Committee was reliant on the resources and expertise of the firm in order to provide accurate translation.

Following the recruitment of the twelve tea cultivators in August 1839, Matheson explained to Wallich the difficulties caused by the start of the First Opium War. Matheson wrote that 'in these troublesome times ... the attention of the Chinese Govt. has lately been drawn to the subject, and they have issued many severe proclamations against those who may aid or abet the emigration of their subjects'. ${ }^{124}$ In the last round of Chinese recruitment to be conducted by the firm for the Assam experiment Matheson was able to recruit fourteen tea cultivators as well as eight lackerers and box makers, meeting the requirements that had been

\footnotetext{
${ }^{120}$ Ibid.

${ }^{121}$ Agreement with Low-a-sam, Tea Cultivator, (15th August 1839), in MS JM/F11/3, Jardine Matheson Archive (Cambridge University).

${ }^{122}$ Matheson, The Present Position and Prospects of the British Trade with China, p. 1.

${ }^{123}$ Edward LeFevour, Western Enterprise in Late Ch'ing China: A Selective Survey of Jardine, Matheson \& Company's Operations, 1842-1895, Harvard University Press, Cambridge, 1968, p. 22.

${ }^{124}$ James Matheson, Hong Kong, to Dr. N. Wallich, Calcutta, (25 September 1839), in MS JM/C10, Jardine Matheson Archive (Cambridge University).
} 
outlined by Wallich. These recruits were shipped to Calcutta aboard the firm's trading vessels the Charlotte and the Red Rover. ${ }^{125}$ Unfortunately for the Tea Committee, the commencement of the Opium War destabilised the firm's access to the areas of the China coast from which they had recruited tea cultivators. Language was also still a problem in Assam, where Wallich wished to find one Chinese representative to act as a headman and interpreter. Matheson explained to Wallich that 'Canton men do not use the same spoken language nor do they have the requisite authority over their countrymen of a different province'. ${ }^{126}$ The fact that Matheson was able to recruit at all in the context of rapidly worsening Anglo-Chinese relations (caused in no small part by his own firm's activities) was testament to the firm's networks that transcended both Chinese and British imperial control.

\section{The Success of Assam and the Failure of Chinese Labour}

From the very conception of the Assam experiment the EIC had planned to transfer the tea plantations to private ownership. ${ }^{127}$ Following the success of the first Assam teas the Assam Company was incorporated in 1839, with the new Company in control of production in Assam by the first tea season of $1840 .{ }^{128}$ The Assam Company, with its high levels of available capital hired Dr Lumqua, who had been too expensive for the Tea Committee, to manage the Chinese workers in Assam and arrange further Chinese recruitment. ${ }^{129}$ On the advice of Lumqua a Chinese agent (styled Eekan or E-kan) was appointed to hire Chinese labourers from Penang and Singapore. ${ }^{130}$ Eekan was able to recruit 216 labourers from Penang and 245 from Singapore but, in these easily accessible contact zones outside of China, he was 'not successful in finding any experienced artisans'. ${ }^{131}$ Instead these recruits were intended to become apprentices under tea makers already in Assam who would develop into skilled tea artisans. Additionally, Lumqua procured a messenger to travel across Burma and attempt to establish a supply of skilled Chinese labour from the Chinese province of Yunnan. ${ }^{132}$ In spite of the large numbers of labourers acquired from Penang and Singapore, Lumqua's attempt to source skilled labour from Yunnan demonstrates the premium placed on skilled artisans from China itself. A colonial hierarchy that placed Chinese migrants from China above Chinese migrants from the Straits Settlements was emerging, and was informed by the premium placed on specialist skill and useful knowledge.

The Chinese recruitment undertaken by the Assam Company was vastly more problematic than the recruitment of Jardine Matheson. In February 1840 nine Chinese labourers, out of a group of 105 intended for Assam, were arrested and put on trial for assault at Bogra. Bruce warned that too many Chinese workers were arriving as he was still in the

\footnotetext{
125 Ibid.

126 Ibid.

${ }^{127}$ Webster, The Twilight of the East India Company, p. 119.

${ }^{128}$ Wilson Gow and Stanton Gow (eds), Tea Producing companies of India and Ceylon: showing the History and Results of those Capitalised in Sterling, A. Southey \& Co., London, 1897, p. 3.

${ }^{129}$ Dr Lumqua's salary of 1,110 Rs. can be compared to the total labourers advance of 20,586 Rs. prior to $31^{\text {st }}$ December 1839, from Report of the Bengal Branch of the Assam Company, Samuel Smith \& Co., Calcutta, 1840, p. 17.

${ }^{130}$ Report of the Bengal Branch of the Assam Company, p. 9.

131 Ibid.

${ }^{132}$ Ibid, p. 10.
} 
government's military service and could not devote the time to manage the plantation. ${ }^{133}$ Eekan's shipment of Chinese labourers from Singapore arrived the next month. However, after 57 labourers were arrested over an affray in which a local was killed at Pabna, the remainder of the 'gang' refused to move to Assam without a 'further advance of pay, and supplies of opium and provisions'. ${ }^{134}$ After three months the group was completely abandoned, though the Assam Company regretted 'that so many lawless characters should be let loose upon society'. ${ }^{135}$ The failure was specifically attributed to poor selection by Eekan and the poor 'character' of the Chinese from Penang and Singapore. Additionally, those who did reach the stations in Assam fell victim to fever - a common occurrence in the Assamese jungle. Similarly, Lumqua's alternative mission to Yunnan was thwarted by 'the cowardice and roguery of the Chinese' who had been hired to undertake the journey but disappeared without a trace shortly after departing. ${ }^{136}$ The failure of these schemes, both to source unskilled labour from Singapore and skilled artisans from Yunnan, cost the Assam Company vast amounts of money. ${ }^{137}$ Such recruitment projects were also doomed by the death of Lumqua in August 1840 who, according to the 1841 Report of the Local Directors, had been 'appoint a kind of Captain, with Magisterial powers, among his countrymen' ${ }^{138}$ As a result the Assam Company began to seek alternative forms of labour.

From early in the Assam Company's ownership and management of the Assam plantations emphasis was placed on the diffusion of the specialist knowledge and abilities away from the specialist Chinese artisans. For example, the first annual report of the Assam Company remarked how one particular establishment had produced tea, despite consisting of 'only two Chinese black tea makers, with twelve native assistants'. ${ }^{139}$ There was a growing realisation on the ground in Assam that the Chinese were becoming superfluous to tea production and their numbers gradually decreased. J. P. Parker, Superintendent of the East Division, discussed how when seven Chinese tea makers were 'discharged' after refusing to relocation to a different division, leaving only two, the establishment was able to continue tea cultivation without them. ${ }^{140}$ A contributing factor to the move away from Chinese recruitment was the employment of indigenous labour. In 1841 Charles Bruce noted how the 'wild people' of the 'Naga tribes' were first induced to help in the labour of clearing the jungle. ${ }^{141}$ The heavy financial cost of the failed Singapore and Yunnan recruitments especially turned the Company's attention to a local labour supply. The 1841 Assam Company Report noted that the 'Assamese are beginning to work, and for the important art of Tea manufacture, they seem

\footnotetext{
${ }^{133}$ Ibid, p. 378; Note the implication that the Chinese required British supervision.

${ }^{134}$ Assam Company, Report of the Local Directors made to the Shareholders at a General Meeting, held at Calcutta, August 11 ${ }^{\text {th }}$, 1841, Bishop's College Press, Calcutta, 1841, p. 5.

135 Ibid.

${ }^{136} \mathrm{Ibid}$, p. 25.

${ }^{137}$ Assam Company, Report of the Local Directors made to the Shareholders at a General Meeting, 1841 , p. 6.

${ }^{138}$ Ibid, p.7; Mann, The Early History of the Tea Industry in North-East India, p. 24.

${ }^{139}$ Assam Company, Report of the provisional committee made to the shareholders and a general meeting, held

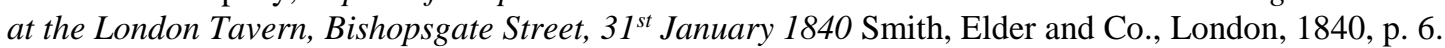

140 Assam Company, Report of the Local Directors made to the Shareholders, at a General Meeting, Held at Calcutta, $6^{\text {th }}$ October, 1842 William Rushton and Co., Calcutta, 1842; J.P. Parker, Superintendent, East Division to R. H. Buckland, Secretary, Assam Company, Calcutta, Jaipore, Upper Assam, $9^{\text {th }}$ August 1842.

${ }^{141}$ Assam Company, Report of the Local Directors made to the Shareholders at a General Meeting, 1841 , p. 12.
} 
peculiarly adapted, and likely to supply eventually all the labour that will be required'. ${ }^{142}$ Importantly, experience over the 1830s had led to a more nuanced view of the different ethnic groups in Assam.

The 1841 Report also explained that the tea of the 1839 season was 'made by Takelans, inhabitants of Assam; and their manufacture was considered, in every respect, as good as that of the Chinese artizan'. ${ }^{143}$ The previously dismissed 'natives' were contributing their knowledge of tea preparation and providing skilled labour. As a result the difficult recruitment of Chinese specialists became increasingly unnecessary. A letter from a $\mathrm{Mr}$ Masters accompanying a tea invoice in late 1841 stated that 'the whole of it has been made without the aid of the Chinamen, and that only one person on the establishment had ever seen a Chinaman engaged in the manufacture'. ${ }^{144}$ By 1842 there was no longer a necessity for the recruitment of Chinese artisans as their expertise was no longer required and had been replaced by cheaper, locally-sourced labour. Additionally, the Assam Company lacked the networks or resources to effectively manage large numbers of Chinese labourers, many of whom had been hired for job roles that they could not fulfil. Luckily for the Assam Company, thanks to the diffusion of specialist knowledge in the 1830s, such recruitment was no longer required. By the 1860 s there were no Chinese tea cultivators or labourers left in Assam. ${ }^{145}$ Instead, the Assam plantations relied on migrant labour from elsewhere in India. Between 1870 and 1900 almost 750,000 labourers arrived in Assam, with 250,000 coming from the Chota Nagpur States. ${ }^{146}$ This labour force operated under a system of indenture contracts and was strictly controlled by the planters, whose interests were protected by colonial legislation. ${ }^{147}$ By the end of the nineteenth century Assam had been transformed into a patchwork of vast and profitable tea plantations. Though Chinese labour was no longer needed, this process had been initiated thanks to the expert knowledge of the Chinese tea cultivators of the 1830s.

Much of the discussion around the use of Chinese and Assamese labour on the tea plantations fed into and contributed to notions of hierarchy. Despite the catastrophe of the Assam Company's era recruitment, the perception of the Chinese as an especially industrious ethnic group was left relatively unharmed. The failure of Chinese labour at Assam was most commonly attributed to poor recruitment, particularly after Jardine Matheson's involvement had ceased. Notably, the later recruitment had not been from the tea producing regions of Southern China, but from the Straits Settlements of Singapore and Penang. The Assam Company complained that those recruited at Singapore by Eekan had been 'selected without discretion' and that they were 'turbulent, obstinate, and rapacious'. ${ }^{148}$ Similarly, the newspaper editor and author Robert Mudie criticised the Assam Company recruits for a 'want of mental dignity'. ${ }^{149}$ As Jayeeta Sharma has pointed out, when discussing botanist William Griffith, discussions of Chinese emigrants in Assam were increasingly imbued with ideas about purity

\footnotetext{
${ }^{142}$ Assam Company, Report of the directors and auditors made to the shareholders and a general meeting, 1841, p. 18. 
and hierarchy. ${ }^{150}$ Griffith was sceptical of Chinese who had spent too long outside of China: 'I found that among all the so-called Chinese, who are to be met with at Mogoung, Bamo, and Ava, as well as among those who form the large annual caravans that trade with Burma, there is not a single genuine Chinaman. ${ }^{151}$ The use of 'genuine' here implies an ethnic hierarchy emerging within the construct of 'the Chinese'. In particular it acted as an appraisal of the China coast recruitment undertaken by Jardine Matheson, which the Assam Company tried to replicate overland from Yunnan, rather than the subsequent recruitment from Southeast Asia. The failure of Assam Company recruitment highlights the importance of Jardine Matheson's opium distribution networks for extracting skilled labour from China. That the Assam Company abandoned the recruitment of Chinese labour within a year of taking control demonstrates both the successful diffusion of specialist knowledge and the limited resource networks of the new organisation.

\section{Conclusion}

This examination of the role of Jardine Matheson in procuring Chinese tea cultivators for Assam has highlighted the growth of commercial networks on the China coast in the 1830s and the growing importance of private merchant firms. As Jardine Matheson's networks expanded their business interests became more diverse, and they became directly involved in the development of the British Empire. In this context partners and employees of the firm undertook multiple roles. Charles Gutzlaff, though he acted primarily as a missionary, an interpreter and an author, had the necessary skills and expertise to locate opium markets or procure tea cultivators. The use of exploratory opium voyages for recruitment indicate the multiple ways in which the firm was 'opening' China in the 1830s. ${ }^{152}$ Not only was opium being sold and religious literature being disseminated, we also find labour, physical resources and knowledge being extracted. Somewhat ironically the very firm that was at the forefront of jeopardizing Anglo-Chinese relations, and therefore Britain's tea supply, also played a crucial role in establishing the rival Indian tea plantations. Jardine Matheson's role in the tea experiment not only shows a side to the firm's activities that has been under-explored, namely their role in Chinese emigration, but also the emerging autonomy of private British merchant firms on the China coast whose interests and actions would shape Anglo-Chinese relations over the following decades. Recruitment for Assam demonstrates that rather than undermining the colonial, or imperial, state the actions of private firms, whether legal or illegal, were vital to the development of colonial economies. In the same way that Claude Markovits has noted 'smuggling can be said to be structurally linked to the creation of state borders', Jardine Matheson's opium smuggling was linked to the creation of state-managed plantation agriculture in Assam. ${ }^{153}$

\footnotetext{
${ }^{150}$ Sharma, Empire's Garden, p. 37.

${ }^{151}$ Report on the Tea plant of Upper Assam, by Assistant-surgeon William Griffith, Madras Establishment, late member of Assam Deputation, Parliamentary Papers, Tea Cultivation, p. 104.

${ }^{152}$ Gutzlaff, China Opened.

${ }^{153}$ Claude Markovits, 'The Political Economy of Opium Smuggling in Early Nineteenth Century India: Leakage or Resistance?', Modern Asian Studies, Vol. 43, No. 1, 2009, p. 109.
} 
The recruitment and use of Chinese tea cultivators in Assam also fed into developing racial hierarchies. Contrasts were formed between the Assamese and the British; the Chinese and the British; the Chinese and the Assamese; and, increasingly, between specific Assamese tribal or Chinese regional groups. It is of note that after increased experience of recruiting and employing Chinese labour, perceived hierarchies of different Chinese groups emerged. The discussion over what was a 'genuine' Chinese tea cultivator implied questions over purity and definitions of who was or was not Chinese. As with the Assamese, the appraisal of different groups was contingent on their economic utility. Importantly, racial stereotypes, whether focused on Assamese 'savagery' or Chinese 'treachery', were conducive to the broader economic aims of the EIC and British merchant firms on the China coast. Such hierarchies were not static, but shifted over time and across different geographical spaces. Evidently, as a developing colonial space Assam was an early testing ground for ideas about Chinese labour.

The rapid transformation of Assam, with India overtaking China as the world's largest exporter of tea by the end of the nineteenth century, has been the focus of several scholarly texts discussed in this article. ${ }^{154}$ However, as demonstrated by the role of Jardine Matheson in the procurement of Chinese labour, this development cannot be studied in isolation from developments in Anglo-Chinese relations or the British Empire in Asia more generally. By providing an alternative tea supply the development of Assam fundamentally reduced Britain's trade dependency on China, whilst Indian opium exports increased Chinese economic dependency on Britain. Jardine Matheson's involvement in extracting the skilled labour from China that would facilitate this shift indicates the inter-related strands of Anglo-Indian, AngloChinese and Indo-Chinese trade. The story of Chinese emigration to Assam not only informs our understanding of the formation of racial hierarchy in colonial India, but it sheds light on the wider commercial expansion of private British merchant firms in Asia in the 1830s.

${ }^{154}$ Most notably the work of Jayeeta Sharma. 


\section{Sources}

Anonymous, Assam: a sketch of its history, soil, and productions, Smith, Elder \& Co., London, 1839.

Antrobus, H. A., The History of the Assam Company, 1839-1953, T. and A. Constable Ltd., Edinburgh, 1957.

Asiatic Journal, Vol. 26, 1838.

Assam Company, CLC/B/123, London Metropolitan Archives (London).

Assam Company, Report of the Local Directors made to the Shareholders at a General Meeting, held at Calcutta, August 11 ${ }^{\text {th }}$, 1841, Bishop's College Press, Calcutta, 1841.

Assam Company, Report of the provisional committee made to the shareholders and a general meeting, held at the London Tavern, Bishopsgate Street, $31^{\text {st }}$ January 1840, Smith, Elder and Co., London, 1840.

Assam Company, Report of the Local Directors made to the Shareholders, at a General Meeting, Held at Calcutta, $6^{\text {th }}$ October, 1842, William Rushton and Co., Calcutta, 1842.

Gaiutra Bahadur, Coolie Woman: The Odyssey of Indenture, Hurst \& Co., London, 2013.

Ball, Samuel, An Account of the Cultivation and Manufacture of Tea in China, Longman, London, 1848.

Berg, Maxine, 'Britain, Industry and Perceptions of China: Matthew Boulton, 'useful knowledge' and the Macartney Embassy to China', Journal of Global History, 2006, pp. 269288.

Bickers, Robert, The Scramble for China: Foreign Devils in the Qing Empire, 1832-1914 Allen Lane, London, 2011.

Bickers, Robert, 'The Challenger: Hugh Hamilton Lindsay and the rise of British Asia, 18321865', Transactions of the Royal Historical Society, 6th series, 22, 2012.

Blake, Robert, Jardine Matheson: Traders of the Far East, Weidenfield and Nicholson, London, 1999.

Bruce, C. A., An Account of the Manufacture of the Black Tea, As now practised at Suddeya in Upper Assam, Bengal Military Orphan Press, Calcutta, 1838.

Canton Register, 6 October 1835. 
Carroll, John M., 'The Canton System: Conflict and Accommodation in the Contact Zone', Journal of the Royal Asiatic Society Hong Kong Branch, Vol. 50, 2010, pp. 51-66.

Chen, Songchuan, 'An Information War Waged by Merchants and Missionaries at Canton: The Society for the Diffusion of Useful Knowledge in China, 1834-1839', Modern Asian Studies, Vol. 46, No.6, 2012, pp. 1705-1735.

Chong, W. E., Mandarins and Merchants: Jardine Matheson \& Co., a China agency of the early nineteenth century, Curzon Press, London, 1979.

Connell, Carol Matheson, A Business in Risk: Jardine Matheson and the Hong Kong Trading Industry, Praeger, London, 2004.

Crawfurd, John, View of the Present state and Future Prospects of the Free Trade and Colonisation of India, James Ridgway, London, 1829.

Dirks, Nicholas, The Scandal of Empire: India and the Creation of Imperial Britain, Harvard University Press, London, 2008.

Endacott, G. B., A Biographical Sketch-Book of Early Hong Kong, Hong Kong University Press, Hong Kong, 2005.

Gao, Hao, "Prelude to the Opium War? British reactions to the "Napier Fizzle" and attitudes towards China in the mid eighteen-thirties', Historical Research, Vol. 87, No. 237, 2014, pp. 491-509.

Gordon, G. J., Address to the People of Great Britain; Explanatory of our Commercial Relations with the Empire of China, Smith, Elder and Co., London, 1836.

Gordon, G. J., 'Visit to the Ankoy Tea-District', The Asiatic Journal and Monthly Register, Vol. 17, 1835, pp. 281-289.

Gow, Wilson and Gow, Stanton (eds), Tea Producing companies of India and Ceylon: showing the History and Results of those Capitalised in Sterling, A. Southey \& Co., London, 1897.

Gutzlaff, Charles, A Journal of Three Voyages Along the Coast of China; in 1831, 1832 \&1833, London: Frederick Westley and A. H. Davis, London, 1834.

Gutzlaff, Charles, China Opened, Vol. I, Smith, Elder and Co., London, 1838.

Gutzlaff, Charles, Journal of a Residence in Siam: and of a Voyage Along the Coast of China to Manchou Tartary, Chinese Repository, Canton, 1832. 
Hillemann, Ulrike, Asian Empire and British Knowledge: China and the Networks of British Imperial Expansion, Palgrave Macmillan, New York, 2009.

Jardine Matheson Archive, (Cambridge University Library) [http://janus.lib.cam.ac.uk/db/node.xsp?id=EAD/GBR/0012/MS\%20JM], accessed 7 May 2016.

Keswick, Maggie (ed.), The Thistle and the Jade: A Celebration of Jardine, Matheson \& Co., Octopus, London, 1982.

Kumagai, Yukihisa, Breaking into the Monopoly: Provincial Merchants and Manufacturers' Campaigns or Access to the Asian Market, 1790-1833, Brill, Boston, 2013.

Lawson, Philip, The East India Company: A History, Longman, London, 1993.

LeFevour, Edward, Western Enterprise in Late Ch'ing China: A Selective Survey of Jardine, Matheson \& Company's Operations, 1842-1895, Harvard University Press, Cambridge, 1968.

Le Pinchon, Alain (ed.), China trade and empire: Jardine, Matheson \& Co. and the origins of British rule in Hong Kong, 1827-1843, Oxford University Press, Oxford, 2006.

Lutz, Jessie Gregory, Opening China: Karl F. A. Gutzlaff and Sino-Western Relations, 18271852, William B. Eerdmans, Cambridge, 2008.

Mann, Harold H., The Early History of the Tea Industry in North-East India, Reprinted from the Bengal Economic Journal, 1918.

Markovits, Claude, 'The Political Economy of Opium Smuggling in Early Nineteenth Century India: Leakage or Resistance?', Modern Asian Studies, Vol. 43, No. 1, 2009, pp. 89-111.

Matheson, James, The Present Position and Prospects of the British Trade with China, Smith, Elder and Co., London, 1836.

Melancon, Glenn, 'Peaceful Intentions: the First British Trade Commission in China, 1833-5', Historical Research, 73, 2000, pp. 33-47.

Minute book of the Assam Company, 12 February 1839 - 17 December 1845, MS 9924/1, London Metropolitan Archives (London).

Mudie, Robert, China and its Resources, A Notice of Assam, Grattan and Gilbert, London, 1840.

Napier, Priscilla, Barbarian Eye: Lord Napier in China, 1834 The Prelude to Hong Kong, Brassey's, London, 1995. 
Parliamentary Papers, A Bill to Regulate the Trade to China and India, 1833 (528).

Parliamentary Papers, Tea Cultivation (India). Return to an order of the Honourable the House of Commons, dated 15 February 1839;--for, copy of papers received from India relating to the measures adopted for introducing the cultivation of the tea plant within the British possessions in India, 1839 (63).

Peers, Douglas M., 'Bentinck, Lord William Henry Cavendish- (1774-1839)', Oxford Dictionary of National Biography, Oxford University Press, 2004; online edn, Oct 2009 [http://www.oxforddnb.com/view/article/2161, accessed 5 May 2016].

Pitts, Jennifer, A Turn to Empire: the Rise of Imperial Liberalism in Britain and France, Princeton University Press, 2005.

Reading Mercury, 4 May 1835.

Royle, J. Forbes, 'Report on the Progress of the Culture of the China Tea Plant in the Himalayas, from 1835 to 1857 ', Journal of the Royal Asiatic Society, 12, 1850, pp. 125-52.

Scott, James C., The Art of not Being Governed: An Anarchist History of Upland Southeast Asia, Yale University, New Haven, 2009.

Sharma, Jayeeta, 'Lazy Natives, Coolie Labour, and the Assam Tea Industry', Modern Asian Studies, Vol. 43, No. 6, November 2009, pp.1287-1324.

Sharma, Jayeeta, Empire's Garden: Assam and the Making of India, Duke University Press, London, 2011.

Sharma, S. K., and Sharma, Usha (eds), North-East India: Volume 5 Assam-Economy, Society and Culture, Mittal, New Delhi, 2005.

Singapore Chronicle, 6 August 1836.

Taknet, D. K., The heritage of Indian tea: the past, the present, and the road ahead, IIME, Jaipur, 2002.

The Era, 13 January 1839.

Thompson, George, Report of a Public Meeting and Lecture at Darlington ... on China and the Opium Question, J. H. Veitch, Durham, 1840.

Tiedemann, R. G., 'Gützlaff, Karl Friedrich August (1803-1851)', Oxford Dictionary of National Biography, Oxford University Press, 2004

[http://www.oxforddnb.com/view/article/54362, accessed 5 May 2016]. 
Tinker, Hugh, A New System of Slavery: the export of Indian Labour Overseas, 1830-1920, Oxford University Press, London, 1974.

Walton, L. L., Indentured Labour, Caribbean sugar: Chinese and Indian migrants in the British West Indies, 1838-1918, The Johns Hopkins Press, Baltimore, 1993.

Webster, Anthony, The Twilight of the East India Company: The Evolution of Anglo-Asian Commerce and Politics, 1790-1860, Boydell Press, Woodbridge, 2009.

Roland Wenzlhuemer, 'Indian Labour Immigration and British Labour Policy in NineteenthCentury Ceylon', Modern Asian Studies, Vol. 41, Issue 3, May 2007, pp. 575-602.

Williamson, A. R., Eastern Traders: Some Men and Ships of Jardine, Matheson \&Company, Jardine, Matheson \& Co., Hong Kong, 1975.

Yorkshire Gazette, 19 January 1839. 